\title{
The Geographical Distribution of the Physical Properties of Surface Water in Al-Qadisiya Governorate
}

\author{
Hajar Tahseen Ali, Prof. Dr. Salam Hatif Ahmed
}

University of Baghdad- College of Education- Ibn Rushd for Humanitarian Sciences

\begin{abstract}
:
The qualitative indications of water is no less important than its Quantification indications, as the abundance of water is not enough in case of its bad quality, and a better example on this is the water of seas and oceans, as despite the abundance of sea and ocean water, yet it is unsuitable for various uses, as its salinity limits its usability, as well as the water quality has a disparate importance as to its uses, which is shown through the study of physical properties of a group of Al-Qadisiya Governorate rivers.

In this research, (36) samples of water were taken, (18) samples in April represented the theoretical spring season and (18) samples in September represented the theoretical autumn season, three samples for each season and each main river in the study area were represented at the beginning, middle and end of the course in order to study the physical properties of the selected rivers in the study area.
\end{abstract}

\section{Introduction:}

The study of water is considered as one of the significant studies, especially what we face currently of paucity and fluctuation resulted from the scarcity of surface water as a result of the water policies between the adjacent countries which have become apparent in recent years, including the common rivers, as Iraq owns a group of common rivers with the adjacent States, most of which spring from these States, which facilitates their control over them By establishing dams and reservoirs, and thus the water share reaching Iraq is little, making many areas including Al-Qadisiya governorate which suffers from acute decrease in water with the need to raise the country's agricultural and cultural reality through increasing the agricultural spot and establishing plants in order to invest water resources in an optimal way, as well as the importance of these water properties (on the top of which are the physical properties); therefore, the matter necessitated looking for these properties in surface water of the study area.

Problem of the Study: Is there a spatial Variation in the physical properties of surface water in Al-Qadisiya governorate?

Hypothesis of the Study: Water physical properties differ in the study area with the difference of the existing rivers and the difference of samples locations.

Water physical properties, including $(\mathrm{pH})$ values, suspended Solids, soluble salts, electric conductivity, turbidity, water permeability and water temperature, were studied in the surface water of the study area, including (Al-Diwaniya, Al-Daghara, Al-Shammiya, Al-Shannafiya, Al-Masab Al-Aam, Marsh of Al-Dalmag).

Before accessing the analysis of the values of physical elements, we should define them first because they will be studied for the six selected rivers, as the following:

1- (pH): It is the power of hydrogen, which means the activity of the hydrogen ion in water. It is a measure of Alkalinity and acidity, which value ranges between (0-14) and is divided between the numbers lower than (7), i.e. the water is acid, the numbers higher than (7), i.e. the water is alkaline, and number (7) means that the water is neutral[1] 
2- suspended Solids : They are the matters moving outside the bottom layer by river currents during a particular period of time[2].

3- Soluble Salts: They are solids really solving water in that they stay with water in filtration processes, and do not include suspended Solids and soluble gases, and they are also called salinity[3]

4- Electric Conductivity: It is water ability to carry the electric current, and depends on the concentration and equivalence of ions and water temperature[4]

5- Turbidity: It is the capacity to disperse the light projecting on water, and their causes are many including the presence of suspended solids, bacteria, micro-organisms or floating plants[5]

6- Water Temperature: It is the temperature that affects water quality through the increase in the content of sodium chloride and calcium carbonate[6].

\section{The Physical Properties of the Waters of Both Rivers Al-Diwaniya and Al-Daghara:}

Al-Diwaniya river is one of the branches of Shatt-el-Hilla, it runs in the old course of Euphrates river, enters Al-Qadisiya governorate from the north at the region of Forehead Al-Daghara, then it passes through the governorate center, Al-Sideir district and the center of Al-Hamza district, and continues in its direction towards the south until it enters the lands of Al-Muthanna governorate at Imam Al-Hamza in Al-Rumaitha district within the administrative limits of Al-Muthanna governorate[7]while Al-Daghara river represents the second branch of Shatt-el-Hilla, and enters from the north of the governorate at the region of Forehead AlDaghara (the site of branching is Shatt-el-Hindiya), and runs towards east south in parallel with Al-Hurriya southern stream.

From table (1), high values of $(\mathrm{pH})$ are shown in each of Al-Diwaniya and Al-Daghara rivers in April more than September, as they have registered their highest averages in Al-Diwaniya river in autumn (9.1) in the third sample, while they have registered their lowest averages (8.8) in the first sample, whereas their averages were less in April, as they registered their highest value in Al-Diwaniya river (8.2) in the third sample, while they registered their lowest value (7.9) in the second sample. As for Al-Daghara river, they registered the highest concentrations in September in the third sample with an amount of (8.8), while the lowest concentrations were in April in the first sample with an amount of (8.6) milligram/liter. The highest and lowest concentrations in Al-Daghara river were in April (7.44) and (7.08) in the first and third samples, respectively. The high values of $(\mathrm{pH})$ in general in September and in all the sites of studied samples are resulted from the decomposition of the organic matters due to high temperature, leading to a high concentration of $\mathrm{CO}_{2}$, while low values of $(\mathrm{pH})$ are due to the consumption of $\mathrm{CO}_{2}$ [8] The values of $(\mathrm{pH})$ show that the water of the samples taken from Al-Diwaniya and Al-Daghara rives are of high alkalinity and are characterized by good regulation alkalinity, see maps (1) and (2), and image (1).

As for the suspended materials, it was shown from the same table their height in the six samples of the two rivers, but in April they were higher than in September, and the highest samples in Al-Diwaniya river were registered in the second sample by $(99) \mathrm{mg} / \mathrm{L}$ and the same thing with Al-Daghara river in the third sample, as it registered (96), while the lowest samples in Al-Diwaniya river in April were registered in the first sample (86) and in Al-Daghara river (67).

When reviewing table (1), it is shown that the dissolved salts registered the highest values in April in both rivers Al-Diwaniya and Al-Daghara, where the highest values were in the third sample in Al-Diwaniya river (822.9) $\mathrm{mg} / \mathrm{L}$ and the third sample in Al-Daghara river $(1645.4) \mathrm{mg} / \mathrm{L}$, while the lowest values of dissolved salts were in April (705.4)mg/L in Al-Diwaniya river and (1120.1)mg/L in Al-Daghara river.

The total dissolved salts showed approximate values in Al-Diwaniya river among all samples, and this is due to the salty balance in the main source water, as this river is continually provided with constant quantities of water all through the year. While in Al-Daghara river, the matter is different since the results and findings showed the presence of great and clear variations at the level of samples, as they showed the highest value in the third sample for September $(6340.0) \mathrm{mg} / \mathrm{L}$ and the lowest value in April for the second sample (1117.1)mg/L and this difference here is due to the large water capacity witnessed by the rivers in September, resulting in an increase in salts concentration in addition to what the drains throw of salts which lead to a great increase in salty concentrations. 
From the same table, we see an increase in the value of electric conductivity in April more than September and in Al-Daghara river more than Al-Diwaniya river, and this increase in the electric conductivity value in Al-Daghara river water is due to an increase in its content of the overall dissolved salts which causes were mentioned before, so it registered the highest values in each of them, in Al-Diwaniya river in April was in the third sample (5.1) $\mu \mathrm{S} / \mathrm{cm}$ for turbidity and (19.3), respectively. As for Al-Daghara river, the highest value of electric conductivity was in the first sample (10.2) $\mu \mathrm{S} / \mathrm{cm}$ and the lowest conductivity was (3.58) in the same sample in April, and the third sample in Al-Daghara river registered the highest value of turbidity in April (13.7), while the lowest turbidity was in the second sample in April (4.8).

Table (1) The physical properties of Al-Diwaniya river and Al-Daghara river for the year 2018

\begin{tabular}{|c|c|c|c|c|c|c|c|c|c|c|c|}
\hline \multicolumn{4}{|c|}{ Data } & \multirow{2}{*}{$\begin{array}{c}\begin{array}{c}\text { Eleme } \\
\text { nts }\end{array} \\
\text { Month }\end{array}$} & \multirow{2}{*}{$\begin{array}{c}\mathbf{p H} \\
\\
\text { Power } \\
\text { of } \\
\text { Hydro } \\
\text { gen }\end{array}$} & \multirow{2}{*}{$\begin{array}{c}\text { T.S.S.m } \\
\text { g/L } \\
\\
\\
\text { Suspend } \\
\text { ed } \\
\text { matters }\end{array}$} & \multirow{2}{*}{$\begin{array}{c}\text { T.D.S. } \\
\text { mg/L } \\
\\
\text { Dissol } \\
\text { ved } \\
\text { salts } \\
\text { mg/L }\end{array}$} & \multirow{2}{*}{$\begin{array}{c}\begin{array}{c}\text { E.C. Ds } \\
\mathbf{1 m}\end{array} \\
\\
\text { Electric } \\
\text { conducti } \\
\quad \text { vity } \\
\mu \mathrm{S} / \mathrm{cm}\end{array}$} & \multirow{2}{*}{$\begin{array}{c}\begin{array}{c}\text { Turbi } \\
\text { dity } \\
\text { (NTU) }\end{array} \\
\begin{array}{c}\text { Turbidi } \\
\text { ty }\end{array}\end{array}$} & \multirow{2}{*}{$\begin{array}{c}\begin{array}{c}\text { Depth } \\
\text { (cm) }\end{array} \\
\text { Water } \\
\text { depth } \\
\text { and light } \\
\text { permeab } \\
\text { ility } \\
\text { mg/L }\end{array}$} & \multirow{2}{*}{$\begin{array}{c}\text { Temp. } \\
\text { C } \\
\\
\text { Water } \\
\text { tempera } \\
\text { ture }\end{array}$} \\
\hline River & $\begin{array}{l}\text { Locati } \\
\text { on }\end{array}$ & $\begin{array}{c}\text { Latitu } \\
\text { des }\end{array}$ & $\begin{array}{c}\text { Longitu } \\
\text { des }\end{array}$ & & & & & & & & \\
\hline \multirow[t]{6}{*}{$\begin{array}{c}\text { Diwan } \\
\text { iya }\end{array}$} & $\begin{array}{l}\text { Sampl } \\
\text { e } 1\end{array}$ & $0^{\prime} 32^{\circ}$ & $53^{\prime} 44^{\circ}$ & Sep. & 8.8 & 65 & 705.4 & 1.1 & 4.9 & 298 & 17.5 \\
\hline & $\begin{array}{c}\text { Sampl } \\
\text { e 1-1- } \\
11\end{array}$ & $0^{\prime} 32^{\circ}$ & $53^{\prime} 44^{\circ}$ & Apr. & 8.1 & 86 & 707 & 3.7 & 16.5 & 202 & 37 \\
\hline & $\begin{array}{l}\text { Sampl } \\
\text { e } 2\end{array}$ & $\begin{array}{l}52^{\prime} \\
31^{\circ}\end{array}$ & $56^{\prime} 44^{\circ}$ & Sep. & 8.9 & 72 & 709.0 & 1.19 & 5.2 & 221 & 17 \\
\hline & $\begin{array}{l}\text { Sampl } \\
\text { e 2-2 }\end{array}$ & $\begin{array}{l}52^{\prime} \\
31^{\circ}\end{array}$ & $56^{\prime} 44^{\circ}$ & Apr. & 7.9 & 99 & 775.7 & 4.8 & 18.8 & 131 & 38 \\
\hline & $\begin{array}{l}\text { Sampl } \\
\text { e } 3\end{array}$ & $\begin{array}{l}44^{\prime} \\
31^{\circ}\end{array}$ & $58^{\prime} 44^{\circ}$ & Sep. & 9.1 & 77 & 804.1 & 1.4 & 6.6 & 159 & 17.7 \\
\hline & $\begin{array}{l}\text { Sampl } \\
\text { e 3-3 }\end{array}$ & $\begin{array}{l}44^{\prime} \\
31^{\circ}\end{array}$ & $58^{\prime} 44^{\circ}$ & Apr. & 8.2 & 92 & 822.9 & 5.1 & 19.3 & 107 & 38 \\
\hline \multirow[t]{5}{*}{$\begin{array}{c}\text { Dagha } \\
\text { ra }\end{array}$} & $\begin{array}{l}\text { Sampl } \\
\text { e } 1\end{array}$ & $9^{\prime} 32^{\circ}$ & $53^{\prime} 44^{\circ}$ & Sep. & 8.6 & 67 & 1120.1 & 3.58 & 5.5 & 294 & 17 \\
\hline & $\begin{array}{c}\text { Sampl } \\
\text { e 1-1- } \\
11\end{array}$ & $9^{\prime} 32^{\circ}$ & $53^{\prime} 44^{\circ}$ & Apr. & 7.44 & 88 & 2291.0 & 10.2 & 9.6 & 206 & 37 \\
\hline & $\begin{array}{l}\text { Sampl } \\
\text { e } 2\end{array}$ & $6^{\prime} 32^{\circ}$ & $7^{\prime} 45^{\circ}$ & Sep. & 8.7 & 74 & 3422.0 & 5.35 & 4.8 & 215 & 18 \\
\hline & $\begin{array}{l}\text { Sampl } \\
\text { e 2-2 }\end{array}$ & $6^{\prime} 32^{\circ}$ & $7^{\prime} 45^{\circ}$ & Apr. & 7.19 & 95 & 1177.1 & 10.0 & 11.3 & 125 & 38 \\
\hline & $\begin{array}{l}\text { Sampl } \\
\text { e } 3\end{array}$ & $2^{\prime} 32^{\circ}$ & $17^{\prime} 45^{\circ}$ & Sep. & 8.8 & 79 & 6340.0 & 4.07 & 5.2 & 139 & 18 \\
\hline
\end{tabular}




\begin{tabular}{|l|l|l|l|l|l|l|l|l|l|l|l|}
\hline $\begin{array}{c}\text { Sampl } \\
\text { e 3-3 }\end{array}$ & $2^{\prime} 32^{\circ}$ & $17^{\prime} 45^{\circ}$ & Apr. & 7.08 & 96 & 1645.4 & 10.0 & 13.7 & 100 & 39 \\
\hline
\end{tabular}

Source: The researcher's work based on laboratory analyses for the samples taken from (36) locations at the Ministry of Science and Technology, Office of Water and Environment, 2017.

Map (1) The values of (pH) for Al-Diwaniya river samples during April and September 2018

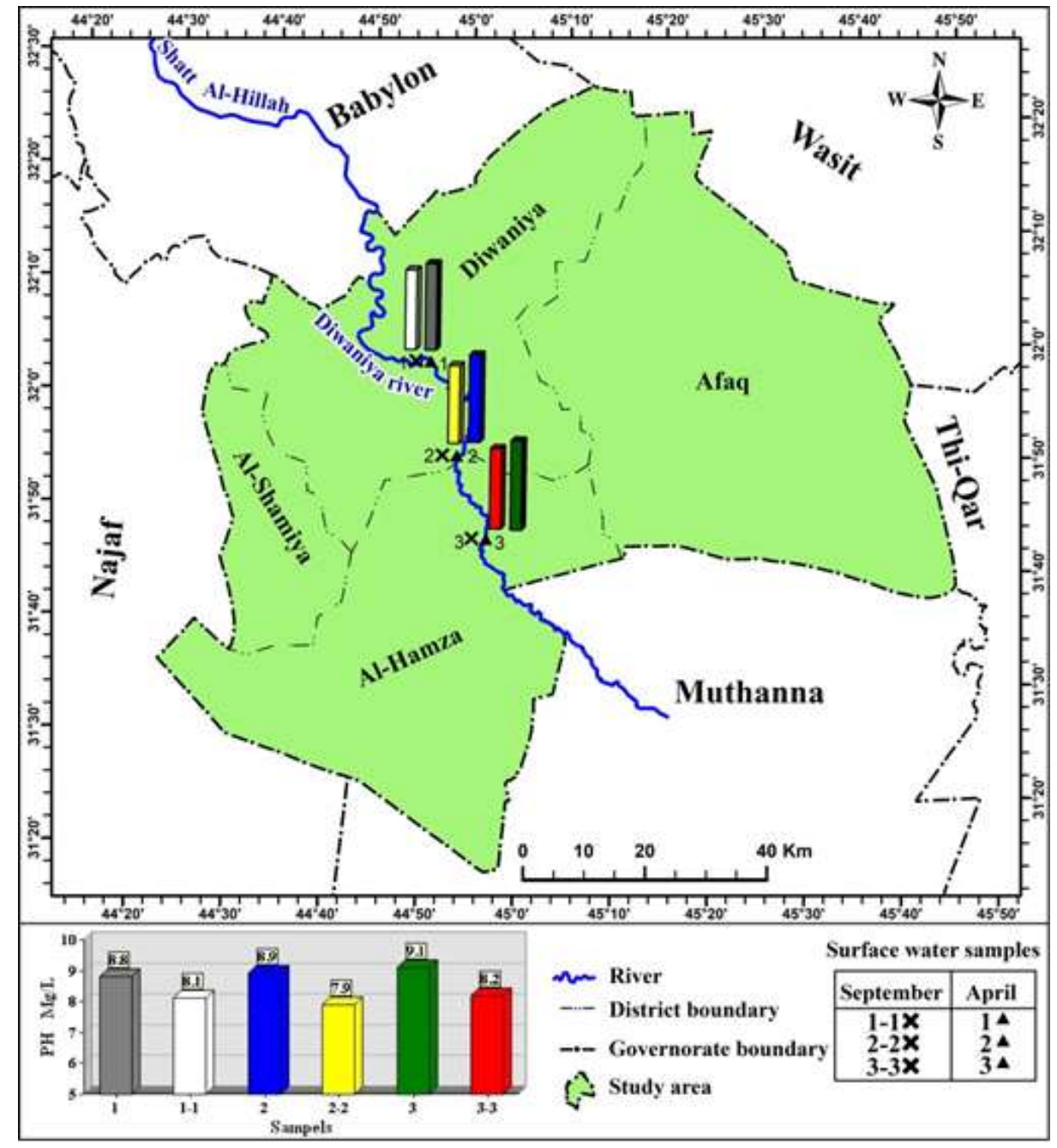

Source: The researcher's work based on the table of sample analysis and topographic maps with the scale $1: 100000$. 


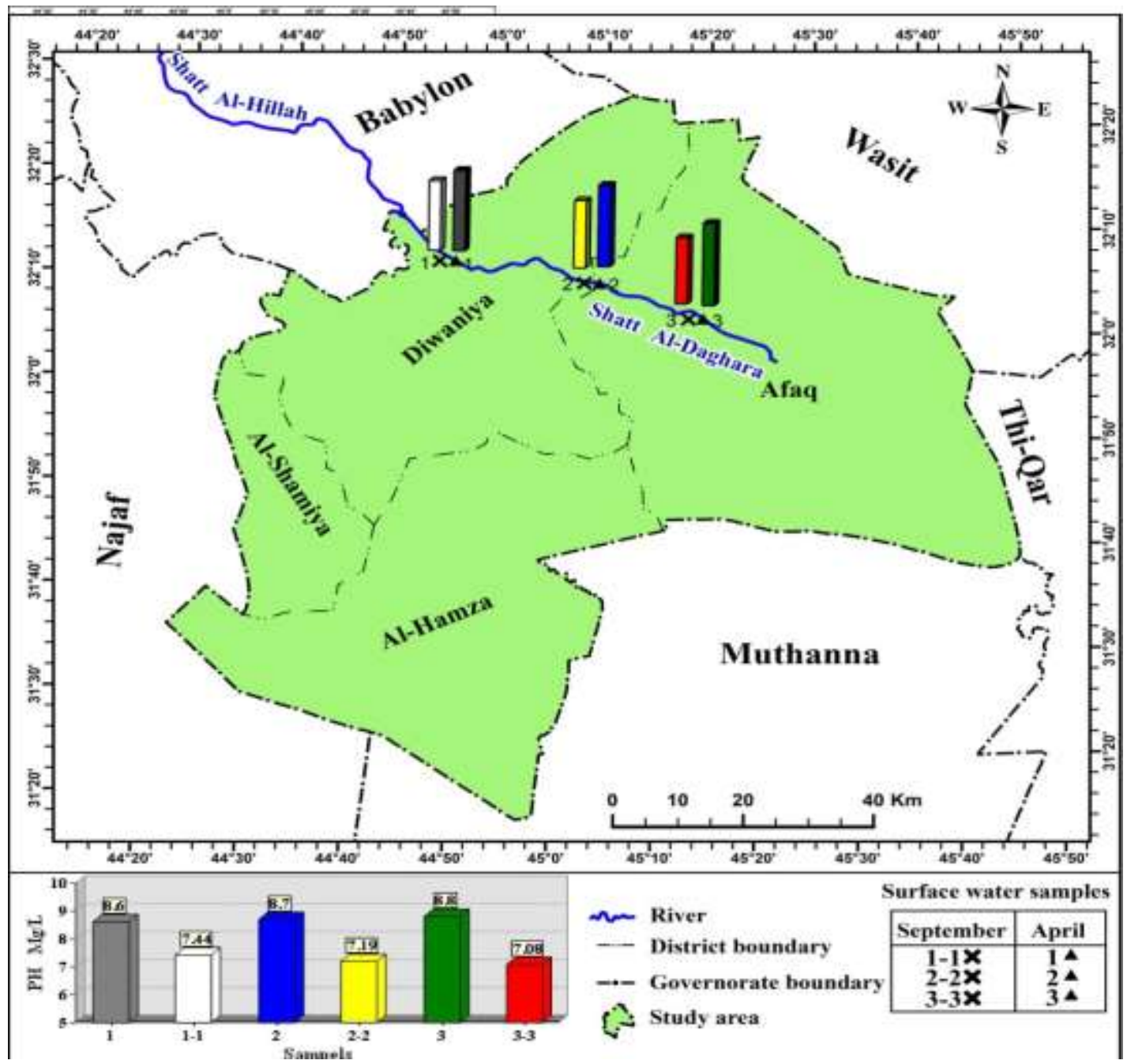

Map (2) The values of (pH) for Al-Daghara river samples during April and September 2018

Source: The researcher's work based on the table of sample analysis and topographic maps with the scale $1: 100000$.

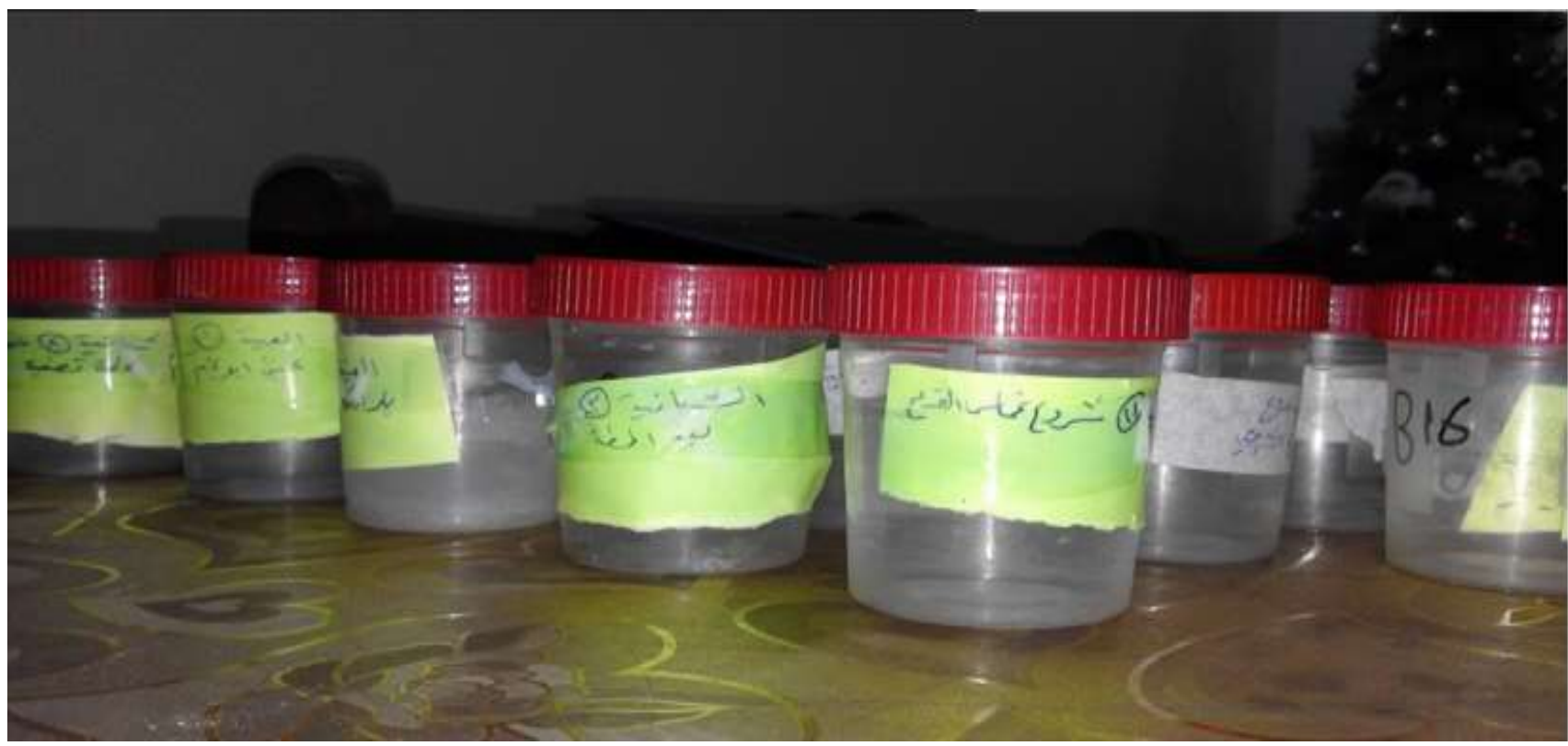

Image (1) Surface water samples for April in the study area

Source: The field study on 6/4/2018. 
The water depth and light permeability had increased in September for all samples, so Al-Diwaniya river registered its highest value in the first sample (298) $\mathrm{cm}$ and the lowest in the third sample (107) $\mathrm{cm}$, while water temperature had increased in April more than September, so it registered in the first sample the lowest values $(17.5)^{\circ} \mathrm{C}$, and in the second and third samples the highest values $(38)^{\circ} \mathrm{C}$ for each of them. The same thing applies to Al-Daghara river, as it registered the highest value of water depth in the first sample (294) $\mathrm{cm}$ in September and the lowest in the third sample (100) $\mathrm{cm}$ in April. The temperature of Al-Daghara river water had increased in April more than September too, so it registered in the first sample the lowest values $(17)^{\circ} \mathrm{C}$ and in the third sample the highest values $(39)^{\circ} \mathrm{C}$.

\section{The Physical Properties of the Waters of Al-Shamiya and Al-Shannafiya Rivers:}

Shatt-el-Shamiya represents one of the branches of Al-Hindiya river, enters from the east north of Al-Qadisiya governorate at Al-Sallahiya district at the kilometer (23.5), and penetrates Ghammas district at the kilometer (71.4), and runs towards the east south in parallel with Al-Hurriya southern stream [9].

As for Al-Shannafiya river, it is a natural extension of Euphrates river in Al-Shannafiya after its passage through Al-Kufa city, as it enters the administrative limits of Al-Qadisiya governorate at the north of Al-Shannafiya district and meets the tails of Shatt-el-Shamiya, and with their meeting, the main Euphrates river, which penetrates the lands of this district, emerges to continue its course afterwards until it enters the lands of Al-Muthanna governorate.

When noting table (2), we see the increase of $(\mathrm{pH})$ values in each of Al-Shamiya and Al-Shannafiya rivers in September more than April, as they registered their highest averages in Al-Shamiya river in September (8.9) in the second and third samples, whereas they registered their lowest averages (8.7) in the first sample, while their averages were lower in April, as they registered their highest value in Al-Shamiya river (8.4) $\mathrm{mg} / \mathrm{L}$ in the third sample, while they registered their lowest value (7.5) in the first sample. As for Al-Shannafiya river, the highest concentrations were registered in September in the third sample by an amount of (9.8), while the lowest concentrations were in April in the first sample by an amount of (8.7), and the highest and lowest concentrations were in Al-Shannafiya in spring (8.8) and (8.6) in the third and first samples, respectively.

The high $(\mathrm{pH})$ values in general in September and in all locations of the studied samples resulted from the decomposition of the organic matters due to high temperature in summer, leading to a high concentration of $\mathrm{CO}_{2} \cdot(\mathrm{pH})$ values show that the sample waters taken from the rivers of Al-Shamiya and AlShannafiya are of acceptable alkaline, characterized by a good organization alkalinity, see maps (3) and (4).

Table (2) The physical properties of Al-Shamiya river and Al-Shannafiya river for the year 2018

\begin{tabular}{|c|c|c|c|c|c|c|c|c|c|c|c|}
\hline \multicolumn{4}{|c|}{ Data } & \multirow{2}{*}{$\begin{array}{c}\begin{array}{c}\text { Elem } \\
\text { ents }\end{array} \\
\begin{array}{c}\text { Mont } \\
\text { h }\end{array}\end{array}$} & \multirow{2}{*}{$\begin{array}{c}\text { pH } \\
\\
\\
\text { Power } \\
\text { of } \\
\text { Hydro } \\
\text { gen }\end{array}$} & \multirow{2}{*}{$\begin{array}{c}\text { T.S.S. } \\
\text { mg/L } \\
\\
\text { Suspen } \\
\text { ded } \\
\text { matters }\end{array}$} & \multirow{2}{*}{$\begin{array}{c}\text { T.D.S } \\
\text { · } \\
\text { mg/L } \\
\\
\text { Dissol } \\
\text { ved } \\
\text { salts } \\
\text { mg/L }\end{array}$} & \multirow{2}{*}{$\begin{array}{c}\text { E.C. } \\
\\
\\
\text { Electric } \\
\text { conduct } \\
\text { ivity } \\
\mu \mathrm{S} / \mathrm{cm}\end{array}$} & \multirow{2}{*}{$\begin{array}{c}\text { Turbi } \\
\text { dity } \\
\text { (NTU } \\
\text { ) } \\
\\
\text { Turbid } \\
\text { ity }\end{array}$} & \multirow{2}{*}{$\begin{array}{c}\text { Depth } \\
\text { (cm) }\end{array}$} & \multirow{2}{*}{$\begin{array}{c}\text { Temp. } \\
\text { C } \\
\text { Water } \\
\text { temper } \\
\text { ature }\end{array}$} \\
\hline River & $\begin{array}{l}\text { Locat } \\
\text { ion }\end{array}$ & $\begin{array}{c}\text { Latitu } \\
\text { des }\end{array}$ & $\begin{array}{c}\text { Longit } \\
\text { udes }\end{array}$ & & & & & & & & \\
\hline \multirow{2}{*}{$\begin{array}{l}\text { Shatt- } \\
\text { el- } \\
\text { Shami } \\
\text { ya }\end{array}$} & $\begin{array}{l}\text { Samp } \\
\text { le } 1\end{array}$ & $\begin{array}{l}59^{\prime} \\
31^{\circ}\end{array}$ & $33^{\prime} 44^{\circ}$ & Sep. & 8.7 & 65 & 951.2 & 4.7 & 5.2 & 291 & 18 \\
\hline & $\begin{array}{l}\text { Samp } \\
\text { le } 1-1\end{array}$ & $\begin{array}{l}59^{\prime} \\
31^{\circ}\end{array}$ & $33^{\prime} 44^{\circ}$ & Apr. & 7.5 & 91 & 989.7 & 11.2 & 10.5 & 202 & 38 \\
\hline
\end{tabular}




\begin{tabular}{|c|c|c|c|c|c|c|c|c|c|c|c|}
\hline & $\begin{array}{l}\text { Samp } \\
\text { le } 2\end{array}$ & $\begin{array}{l}52^{\prime} \\
31^{\circ}\end{array}$ & $36^{\prime} 44^{\circ}$ & Sep. & 8.9 & 77 & $\begin{array}{c}1014 . \\
1\end{array}$ & 4.1 & 6.5 & 217 & 18 \\
\hline & $\begin{array}{l}\text { Samp } \\
\text { le 2-2 }\end{array}$ & $\begin{array}{l}52^{\prime} \\
31^{\circ}\end{array}$ & $36^{\prime} 44^{\circ}$ & Apr. & 7.9 & 97 & $\begin{array}{c}1185 . \\
4\end{array}$ & 12.7 & 12.4 & 128 & 39 \\
\hline & $\begin{array}{c}\text { Samp } \\
\text { le } 3\end{array}$ & $\begin{array}{l}46^{\prime} \\
31^{\circ}\end{array}$ & $37^{\prime} 44^{\circ}$ & Sep. & 8.9 & 81 & $\begin{array}{c}1138 . \\
3\end{array}$ & 4.2 & 6.6 & 141 & 19 \\
\hline & $\begin{array}{l}\text { Samp } \\
\text { le 3-3 }\end{array}$ & $\begin{array}{l}46^{\prime} \\
31^{\circ}\end{array}$ & $37^{\prime} 44^{\circ}$ & Apr. & 8.4 & 94 & $\begin{array}{c}1725 . \\
6\end{array}$ & 13.1 & 14.6 & 103 & 39 \\
\hline \multirow{6}{*}{$\begin{array}{l}\text { Shatt- } \\
\text { el- } \\
\text { Shana } \\
\text { fiya }\end{array}$} & $\begin{array}{c}\text { Samp } \\
\text { le } 1\end{array}$ & $\begin{array}{l}32^{\prime} \\
31^{\circ}\end{array}$ & $40^{\prime} 44^{\circ}$ & Sep. & 9.4 & 75 & 981.1 & 5.2 & 2.6 & 286 & 19 \\
\hline & $\begin{array}{l}\text { Samp } \\
\text { le } 1-1\end{array}$ & $\begin{array}{l}32^{\prime} \\
31^{\circ}\end{array}$ & $40^{\prime} 44^{\circ}$ & Apr. & 8.6 & 98 & $\begin{array}{c}1092 . \\
3\end{array}$ & 6.7 & 3.7 & 204 & 39 \\
\hline & $\begin{array}{c}\text { Samp } \\
\text { le } 2\end{array}$ & $\begin{array}{l}28^{\prime} \\
31^{\circ}\end{array}$ & $51^{\prime} 44^{\circ}$ & Sep. & 9.6 & 79 & $\begin{array}{c}1038 . \\
6\end{array}$ & 4.8 & 2.9 & 229 & 20 \\
\hline & $\begin{array}{l}\text { Samp } \\
\text { le } 2-2\end{array}$ & $\begin{array}{l}28^{\prime} \\
31^{\circ}\end{array}$ & $51^{\prime} 44^{\circ}$ & Apr. & 8.7 & 100 & $\begin{array}{c}1198 . \\
5\end{array}$ & 5.9 & 7.5 & 138 & 40 \\
\hline & $\begin{array}{l}\text { Samp } \\
\text { le } 3\end{array}$ & $\begin{array}{l}25^{\prime} \\
31^{\circ}\end{array}$ & $0^{\prime} 45^{\circ}$ & Sep. & 9.8 & 86 & $\begin{array}{c}1152 . \\
7\end{array}$ & 5.8 & 3.8 & 148 & 21 \\
\hline & $\begin{array}{l}\text { Samp } \\
\text { le 3-3 }\end{array}$ & $\begin{array}{l}25^{\prime} \\
31^{\circ}\end{array}$ & $0^{\prime} 45^{\circ}$ & Apr. & 8.8 & 104 & $\begin{array}{c}1871 . \\
4\end{array}$ & 6.9 & 8.9 & 106 & 41 \\
\hline
\end{tabular}

Source: The researcher's work based on laboratory analyses for the samples taken from (36) locations at the Ministry of Science and Technology, Office of Water and Environment, 2018.

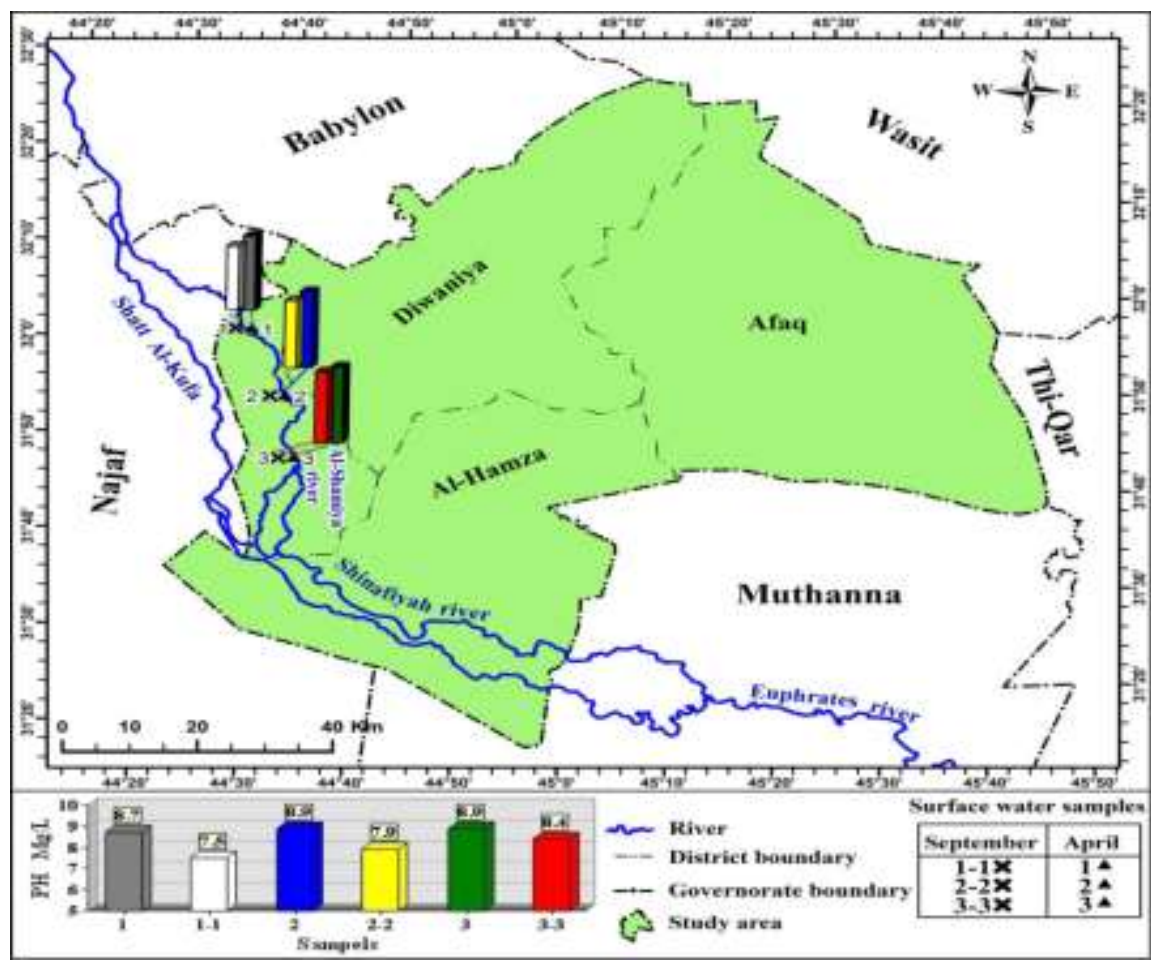


Source: The researcher's work based on the table of sample analysis and topographic maps with the scale 1:100000.

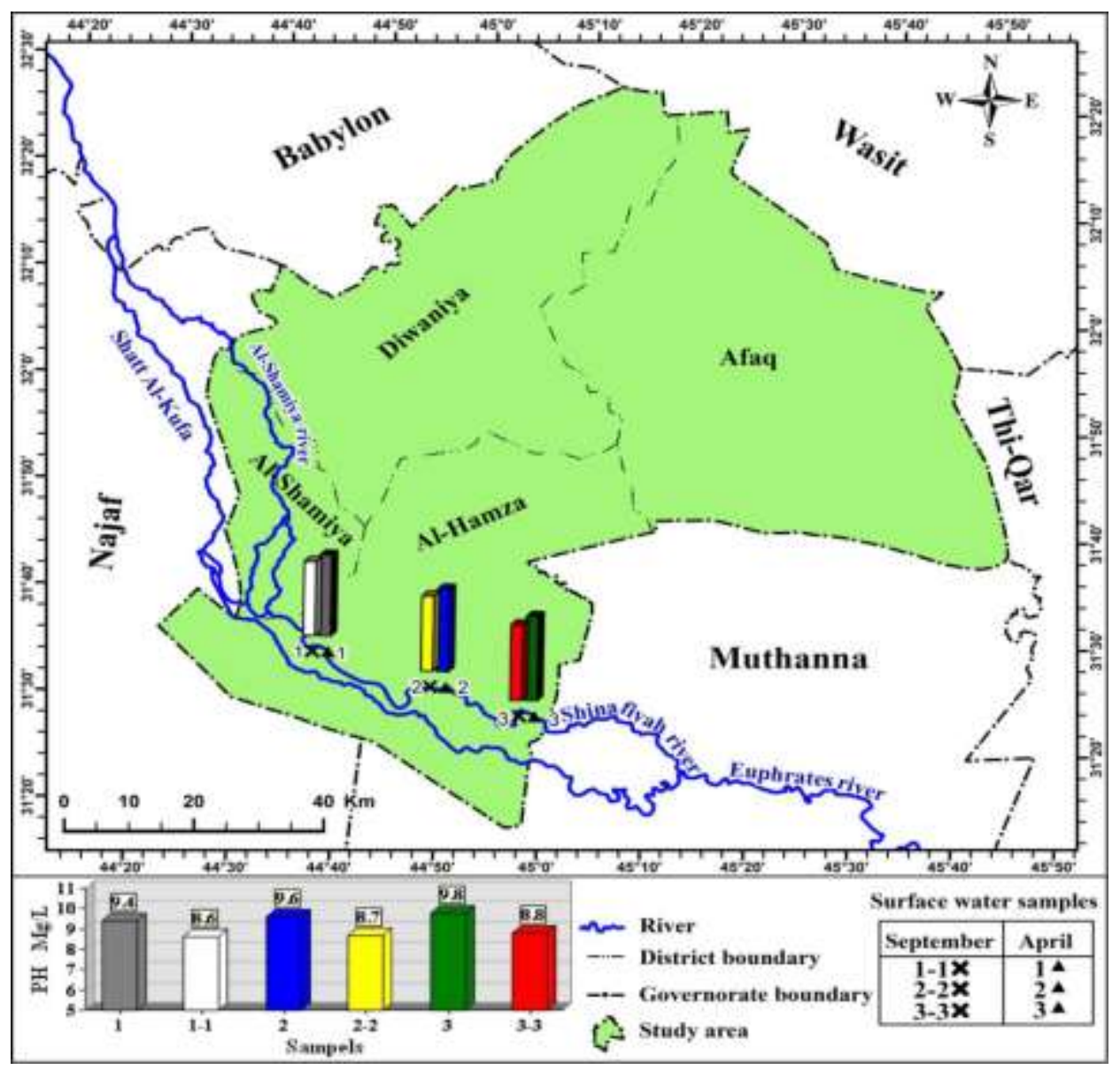

Map (4) The values of (pH) for Al-Shannafiya river samples during April and September 2018

Source: The researcher's work based on the table of sample analysis and topographic maps with the scale 1:100000.

When noting table (2), we see that the dissolved salts has registered the highest values in April in the rivers of Al-Shamiya and Al-Shannafiya, and the highest values in them were in the third sample in AlShamiya river (1725.6)mg/L and the third sample in Al-Shannafiya river (1871.4)mg/L, while the lowest values of dissolved salts in both rivers were in April (951.2), in Al-Shamiya river in the first sample. These values are considered high and they follow the source water content of these two rivers in addition to what reaches them of salts by the drains which throw their waters in these two rivers.

As for the suspended matters, from the same table, it is shown that they are high in the six samples of both rivers, yet they are more in April than in September, and the highest samples have registered in AlShamiya river in the second sample by (97)mg/L and the same matter for Al-Shannafiya river in the third sample, as they registered (104), while the lowest samples in Al-Shannafiya river in spring were in the first sample (98) and in Al-Shamiya river (65), due to the water increase and the frequency of water releases in these both rivers, leading to an increase in the water capacity of erosion which is associated with water increase and the disorder of water course associated with this increase.

The same table shows an increase in the two values of electric conductivity and turbidity in April more than September, so they registered the highest values in Al-Shamiya river in April in the third sample (13.1) $\mu \mathrm{S} / \mathrm{cm}$ and the lowest value was in the first sample (11.2) $\mu \mathrm{S} / \mathrm{cm}$. As for Al-Shannafiya river, the highest electric conductivity was in the first sample (6.9) $\mu \mathrm{S} / \mathrm{cm}$ and the third sample and the lowest electric conductivity was in the second sample in April by an amount of (5.9), and the third sample in Al-Shamiya 
river registered the highest value of turbidity in April (14.6), while the lowest turbidity was in the same sample in September (5.2). The high values of electric conductivity was compatible with the high quantity of total dissolved salts in water, also their values vary according to the variation in water quantity for they rise with the decrease of the levels of water and vice versa.

As for light permeability, it rose in September for all samples, hence Al-Shamiya river registered the highest value of light permeability in the first sample $(291) \mathrm{cm}$ and the lowest value in the third sample $(141) \mathrm{cm}$, while water temperature rose in April more than September, thus it registered in the first and second samples the lowest values $(18.0)^{\circ} \mathrm{C}$, and in the second and third samples the highest values $(39)^{\circ} \mathrm{C}$. The same matter applies to Al-Shannafiya river, in that it registered the highest value of water depth in the first sample (286)cm in September and the lowest in the second sample (138) $\mathrm{cm}$ in April, and the water temperature of Al-Shannafiya river rose in April more than September also, thus it registered in the first sample the lowest values $(19)^{\circ} \mathrm{C}$ and in the second and third samples the highest values $(41)^{\circ} \mathrm{C}$, due to an increase in light permeability because of the great water capacity witnessed by the rivers in September.

\section{The Physical Properties of the Waters of Al-Masab Al-Aam River and Marsh of Al-Dalmag:}

Al-Masab Al-Aam (Tigris - Euphrates) represents the main pillar of drain network in Iraq, as it serves an overall area of (6) million donum of the lands of middle and south Iraq. It is an open water course that starts from Al-Is'haqi Irrigation Project north of Baghdad penetrating the lands of the flowing sedimentary plain ( Iraqi Sedimentary Plain ) between both rivers and its downstream ends up in Shatt-el-Basra and then from there to the Arab Gulf, with its length amounting (564) $\mathrm{km}$. The width of the drain surface ranges from (46)m in its beginning to (100)m in its end [10]As for Marsh of Al-Dalmag, it is a natural depression with an extension north-west and south-east, taking a middle situation between two drains (Al-Masab Al-Aam project (the third river)) from the west which provide Al-Dalmag lake south of the depression with water at the time of its high water levels and their decrease in the lake through a channel called (the feeding channel), located in the western half of the lake, and the second is (Al-Gharraf project) surrounding the lake from the north and the eastern north and draining the very salty water after the process of washing or reforming the soil in the farms located east the lake, i.e. the lands of Al-Damlaj project (Al-Mazzak and Al-Husainiya).

Table (3) shows that the ( $\mathrm{pH})$ values rises in each of Al-Masab Al-Aam river and Hor Al-Damlaj in September more than April, as it registered its highest averages in Al-Masab Al-Aam river in September (9.9) $\mathrm{mg} / \mathrm{L}$ in the third sample, while it registered its lowest averages $(9.6) \mathrm{mg} / \mathrm{L}$ in the first sample, whereas its averages were lower in April, as it registered its highest value in Al-Masab Al-Aam (8.9)mg/L in the second and third samples, while it registered its lowest value $(8.8) \mathrm{mg} / \mathrm{L}$ in the first sample. As for $\mathrm{Al}$ Dalmag Marsh, the highest concentrations were registered in September in the third sample with an amount of $(9.7) \mathrm{mg} / \mathrm{L}$, while the lowest concentrations were in April in the second sample with an amount of $(8.3) \mathrm{mg} / \mathrm{L}$, and the highest concentrations in Hor Al-Damlaj were in spring (8.8) $\mathrm{mg} / \mathrm{L}$ in the third sample, because the rise in $(\mathrm{pH})$ values in general in September and in all locations of the studied samples of AlMasab Al-Aam river and Hor Al-Damlaj resulted in the decomposition of organic matters due to high temperature in summer, leading to a high concentration of $\mathrm{CO}_{2}$, while their decrease is due to the consumption of $\mathrm{CO}_{2}[11]$

Table (3) The physical properties of the water of Al-Masab Al-Aam river and Hor Al-Damlaj

\begin{tabular}{|c|c|c|c|c|c|c|c|c|c|c|c|}
\hline \multicolumn{4}{|c|}{ Data } & $\begin{array}{c}\text { Elem } \\
\text { ents }\end{array}$ & pH & $\begin{array}{l}\text { T.S.S. } \\
\text { mg/L }\end{array}$ & $\begin{array}{c}\text { T.D.S } \\
\text {. }\end{array}$ & $\begin{array}{l}\text { E.C. Ds } \\
1 \mathrm{~m}\end{array}$ & $\begin{array}{c}\text { Turbi } \\
\text { dity }\end{array}$ & $\begin{array}{c}\text { Depth } \\
(\mathbf{c m})\end{array}$ & $\begin{array}{c}\text { Temp. } \\
\text { C }\end{array}$ \\
\hline $\begin{array}{l}\text { Rive } \\
\mathrm{r}\end{array}$ & $\begin{array}{c}\text { Locat } \\
\text { ion }\end{array}$ & $\begin{array}{c}\text { Latitu } \\
\text { des }\end{array}$ & $\begin{array}{c}\text { Longit } \\
\text { udes }\end{array}$ & $\begin{array}{c}\text { Mont } \\
\mathrm{h}\end{array}$ & $\begin{array}{l}\text { Power } \\
\text { of } \\
\text { Hydro } \\
\text { gen }\end{array}$ & $\begin{array}{l}\text { Suspen } \\
\text { ded } \\
\text { matters }\end{array}$ & $\begin{array}{c}\text { Dissol } \\
\text { ved } \\
\text { salts } \\
\mathrm{mg} / \mathrm{L}\end{array}$ & $\begin{array}{c}\text { Electric } \\
\text { conduct } \\
\text { ivity } \\
\mu \mathrm{S} / \mathrm{cm}\end{array}$ & $\begin{array}{c}\text { Turbid } \\
\text { ity }\end{array}$ & $\begin{array}{c}\text { Water } \\
\text { depth } \\
\text { and } \\
\text { light } \\
\text { permea } \\
\text { bility }\end{array}$ & $\begin{array}{l}\text { Water } \\
\text { temper } \\
\text { ature }\end{array}$ \\
\hline
\end{tabular}




\begin{tabular}{|c|c|c|c|c|c|c|c|c|c|c|c|}
\hline & & & & & & & & & & $\mathrm{mg} / \mathrm{L}$ & \\
\hline \multirow{6}{*}{$\begin{array}{c}\text { Al- } \\
\text { Mas } \\
\text { ab } \\
\text { Al- } \\
\text { Aam }\end{array}$} & $\begin{array}{c}\text { Samp } \\
\text { le } 1\end{array}$ & $\begin{array}{l}19^{\prime} \\
32^{\circ}\end{array}$ & $13^{\prime} 45^{\circ}$ & Sep. & 9.6 & 77 & 996.2 & 5.6 & 2.7 & 271 & 20 \\
\hline & $\begin{array}{l}\text { Samp } \\
\text { le } 1-1\end{array}$ & $\begin{array}{l}19^{\prime} \\
32^{\circ}\end{array}$ & $13^{\prime} 45^{\circ}$ & Apr. & 8.8 & 101 & $\begin{array}{c}1103 . \\
5\end{array}$ & 6.9 & 5.9 & 201 & 38 \\
\hline & $\begin{array}{c}\text { Samp } \\
\text { le } 2\end{array}$ & $9^{\prime} 32^{\circ}$ & $20^{\prime} 45^{\circ}$ & Sep. & 9.8 & 81 & $\begin{array}{c}1101 . \\
2\end{array}$ & 5.5 & 3.0 & 212 & 18 \\
\hline & $\begin{array}{l}\text { Samp } \\
\text { le 2-2 }\end{array}$ & $9^{\prime} 32^{\circ}$ & $20^{\prime} 45^{\circ}$ & Apr. & 8.9 & 103 & $\begin{array}{c}1257 . \\
6\end{array}$ & 6.4 & 6.6 & 199 & 39 \\
\hline & $\begin{array}{c}\text { Samp } \\
\text { le } 3\end{array}$ & $\begin{array}{l}59^{\prime} \\
31^{\circ}\end{array}$ & $32^{\prime} 45^{\circ}$ & Sep. & 9.9 & 89 & $\begin{array}{c}1208 . \\
9\end{array}$ & 5.6 & 4.9 & 265 & 21 \\
\hline & $\begin{array}{l}\text { Samp } \\
\text { le 3-3 }\end{array}$ & $\begin{array}{l}59^{\prime} \\
31^{\circ}\end{array}$ & $32^{\prime} 45^{\circ}$ & Apr. & 8.9 & 106 & $\begin{array}{c}1903 . \\
6\end{array}$ & 6.6 & 9.3 & 108 & 40 \\
\hline \multirow{6}{*}{$\begin{array}{c}\text { Hor } \\
\text { Al- } \\
\text { Dam } \\
\text { laj }\end{array}$} & $\begin{array}{c}\text { Samp } \\
\text { le } 1\end{array}$ & $\begin{array}{l}13^{\prime} \\
32^{\circ}\end{array}$ & $23^{\prime} 45^{\circ}$ & Sep. & 9.4 & 75 & 899.9 & 5.4 & 2.5 & 266 & 20 \\
\hline & $\begin{array}{l}\text { Samp } \\
\text { le } 1-1\end{array}$ & $\begin{array}{l}13^{\prime} \\
32^{\circ}\end{array}$ & $23^{\prime} 45^{\circ}$ & Apr. & 8.7 & 99 & $\begin{array}{c}1089 \\
4\end{array}$ & 6.5 & 5.6 & 202 & 37 \\
\hline & $\begin{array}{c}\text { Samp } \\
\text { le } 2\end{array}$ & $9^{\prime} 32^{\circ}$ & $27^{\prime} 45^{\circ}$ & Sep. & 9.6 & 80 & $\begin{array}{c}1098 . \\
0\end{array}$ & 5.3 & 3.1 & 209 & 19 \\
\hline & $\begin{array}{l}\text { Samp } \\
\text { le 2-2 }\end{array}$ & $9^{\prime} 32^{\circ}$ & $27^{\prime} 45^{\circ}$ & Apr. & 8.3 & 102 & $\begin{array}{c}1237 . \\
3\end{array}$ & 6.5 & 6.4 & 195 & 38 \\
\hline & $\begin{array}{c}\text { Samp } \\
\text { le } 3\end{array}$ & $6^{\prime} 32^{\circ}$ & $31^{\prime} 45^{\circ}$ & Sep. & 9.7 & 86 & $\begin{array}{c}1185 . \\
6\end{array}$ & 5.5 & 4.6 & 254 & 20 \\
\hline & $\begin{array}{l}\text { Samp } \\
\text { le 3-3 }\end{array}$ & $6^{\prime} 32^{\circ}$ & $31^{\prime} 45^{\circ}$ & Apr. & 8.8 & 103 & $\begin{array}{c}1872 . \\
0\end{array}$ & 6.7 & 7.7 & 105 & 39 \\
\hline
\end{tabular}

Source: The researcher's work based on laboratory analyses for the samples taken from (36) locations at the Ministry of Science and Technology, Office of Water and Environment, 2018.

As for the suspended matters, the same table shows their increase in all samples, yet they are more in April than in September, and the highest samples in Al-Masab Al-Aam were registered in the third sample by (106)mg/L and the same matter for Hor Al-Damlaj in the third sample, as they registered (103)mg/L, while the lowest samples in Al-Masab Al-Aam river in spring were registered in the first sample (101)mg/L and Hor Al-Damlaj (75)mg/L in the first sample too, due to the large water capacity witnessed by Al-Masab Al-Aam in September because of the water increase for all rivers in this month, resulting in the increase of salts concentrations in addition to what the branch drains throw of salts in it as well as the disordered motion of waters which greatly results in the rise of the values of suspended matters, When noting table (3) and maps (4) and (5), it is shown that the dissolved salts has registered the highest values in April in Al-Masab Al-Aam river and Hor Al-Damlaj, and the highest values in them were in the second sample in Al-Masab Al-Aam river (1257.6)mg/L and also the second sample in Al-Dalmag Marsh (1237.3)mg/L, whereas the 
lowest values of dissolved salts in September in both of them were (899.9)mg/L in the first sample in AlDalmag

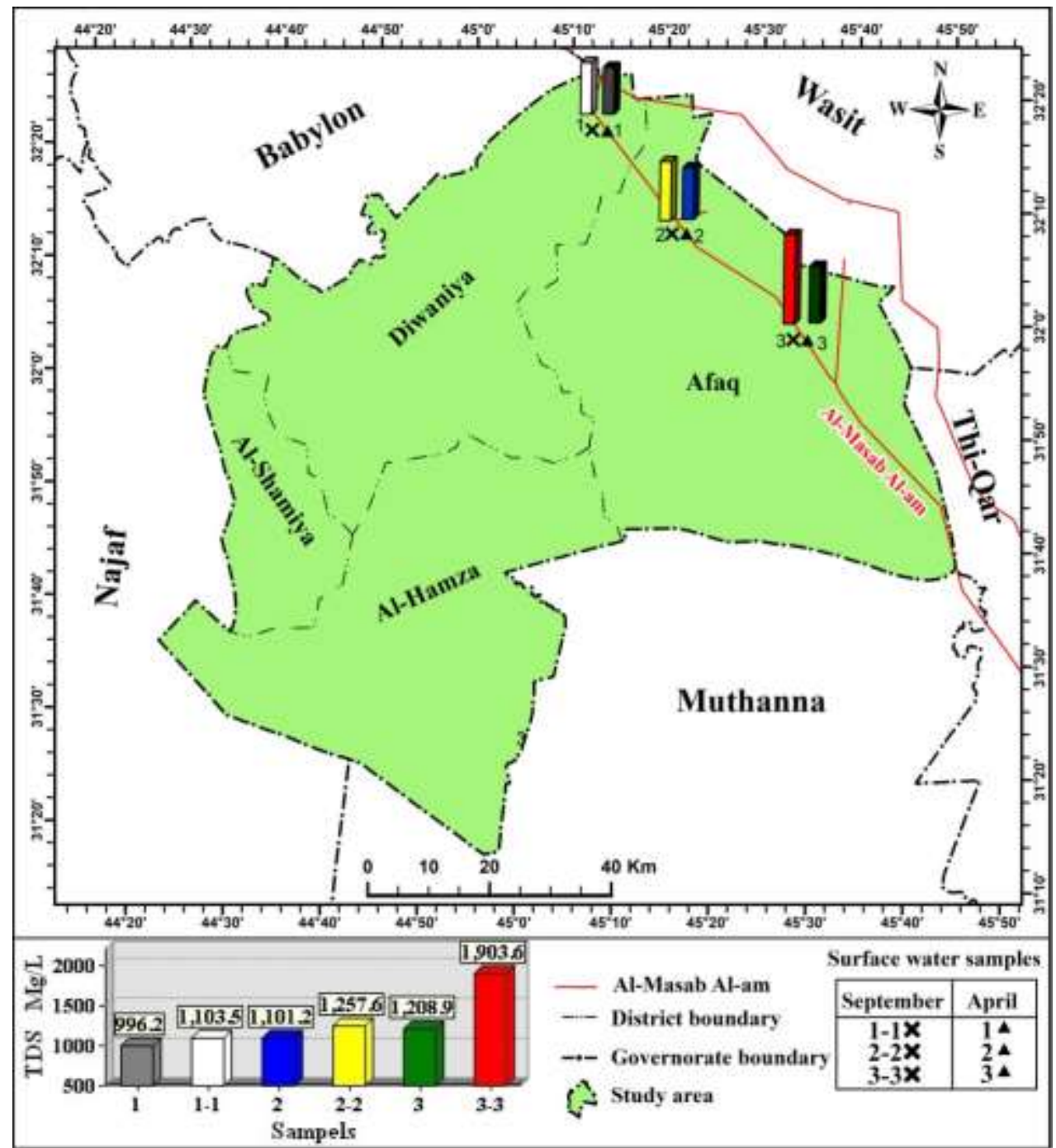

\section{Map (5) The concentrations of dissolved salts for the samples of Al-Masab Al-Aam during April and September 2018}

Source: The researcher's work based on the table of sample analysis and topographic maps with the scale 1:100000.

Marsh, From the same table, we notice a rise in the values of electric conductivity, turbidity, water depth and light permeability in spring more than autumn, so they registered the highest values in Al-Masab Al-Aam river in April for the electric conductivity in the first sample (6.9) $\mu \mathrm{S} / \mathrm{cm}$ and in Al Dalmag Marsh for the same month in the third sample 


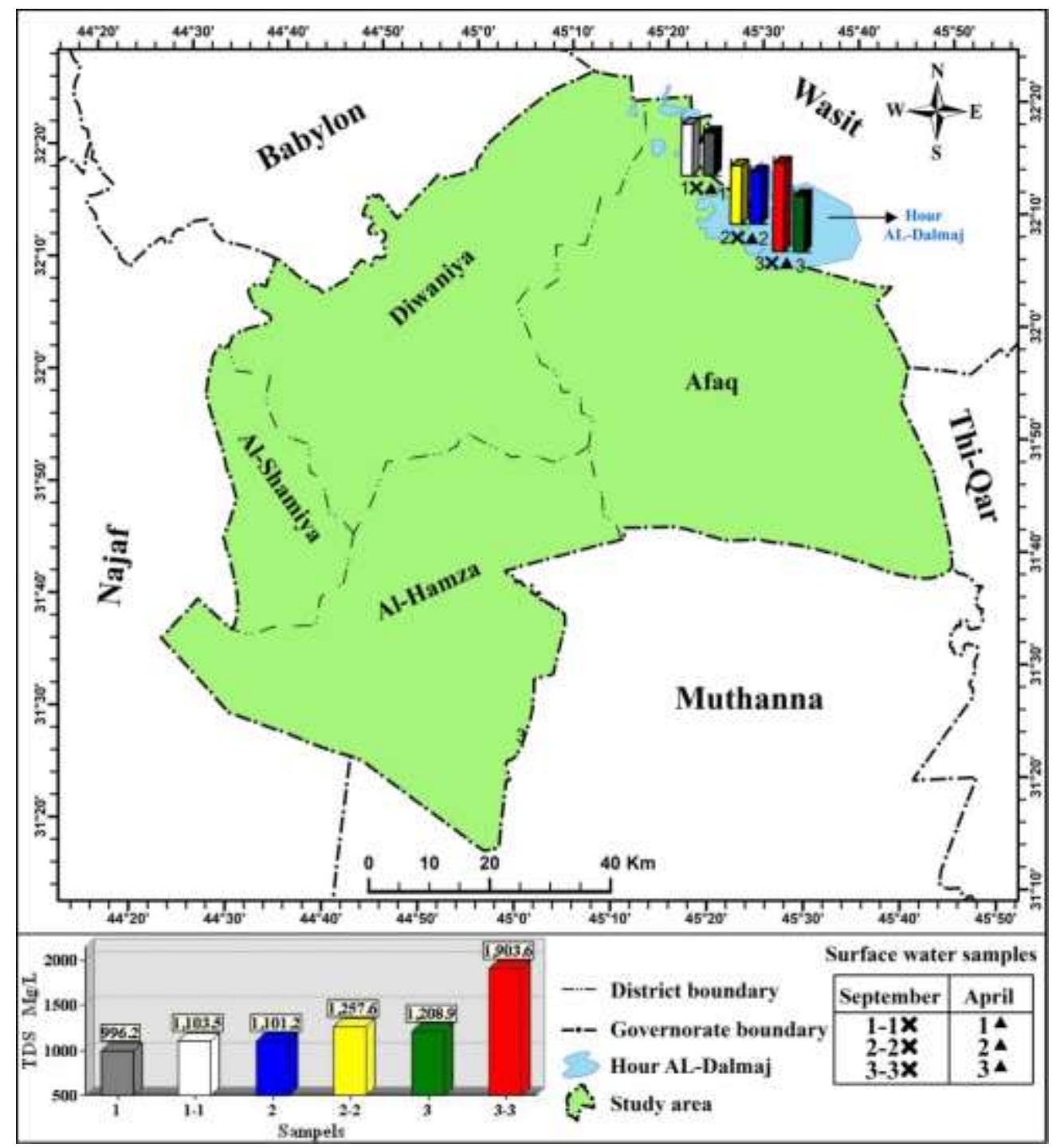

Map (6) The concentrations of dissolved salts for the samples of Al-Dalmag Marsh during April and September 2018

Source: The researcher's work based on the table of sample analysis and topographic maps with the scale $1: 100000$.

(6.7) $\mu \mathrm{S} / \mathrm{cm}$, while the lowest electric conductivity for September in Al-Masab Al-Aam was in the second sample (5.5) $\mathrm{SS} / \mathrm{cm}$, and the lowest conductivity of Hor Al-Damlaj in September was (5.3) for the same sample. Turbidity values rose in April for all samples, thus Al-Masab Al-Aam registered its highest value in the third sample $(9.3) \mathrm{cm}$ and the lowest in the first sample (5.9) $\mathrm{cm}$. In Hor Al-Damlaj, the highest value of turbidity was in the third sample in spring (7.7) and the lowest value for the same season was in the first sample (5.6). As for water temperature, it rose in April more than September, thus it registered in the first sample the lowest values $(20.0)^{\circ} \mathrm{C}$ in Al-Masab Al-Aam and Hor Al-Damlaj, and the highest $(40)^{\circ} \mathrm{C}$ in the third sample in Al-Masab Al-Aam.

\section{Conclusions:}

1- The rise of the measured values of the physical properties with the advance of the river course towards the south of the study area, as they rise in the third sample in most selected rivers, for example the values of $(\mathrm{pH})$ in the third sample for autumn in Al-Diwaniya river which mounted (9.1) and in AlDaghara river in the second sample for spring (8.8) which is the highest value.

2- The rise of the values of dissolved salts and calcium in Al-Masab Al-Aam river and Hor Al-Damlaj in the three samples rather than the rest samples and rivers compared with the international and local standards, as they amount in Hor Al-Damlaj in the third sample for autumn (1185.6)mg/L and 
(1275.6)mg/L in Al-Masab Al-Aam river in the second sample for spring, and these were the highest values recorded for dissolved salts in each of the samples of the selected rivers.

3- Al-Diwaniya river registered the lowest values for the measured physical elements.

4- The high values of the measured physical elements in the selected rivers affected negatively the quality of the waters in them.

\section{Recommendations:}

1- Putting limits and restrictions on throwing the industrial and population wastes in the rivers of the study area through the Ministry of Environment, the Ministry of Health, the Ministry of Water Resources and the institutions affiliated to them in the governorate.

2- Developing the systems of pumps and gates in the rivers of the study area by strengthening and paving them with laying a mechanism for the movement of boats in the courses of the selected rivers that prevent throwing human wastes in them.

\section{References}

1- Abdul Qader Aabed and Others, The Fundamentals of Environment Science, $2^{\text {nd }}$ ed., Dar Wael, Amman, 2010.

2- Ahmed Hussein Hasan, The Spatial Analysis of Ground Water in the Area of Talafar Using Contemporary Techniques, Unpublished Doctorate Thesis, College of Education, Mosul University, 2013.

3- Ali Abdul Zahra Kadhem Al-Wa'eli, Surface Water Resources and Their Impact on Agriculture in AlQadisiya Governorate, Al-Ustath Journal, No. (51), College of Education-Ibn Rushd, University of Baghdad, 2004.

4- Ashwaq Abdul Kareem Hatam, The Geomorphologic Properties of the Course of Al-Kahlaa and AlMashrah Rivers and Their Impacts on Human Activities, Unpublished Doctorate Thesis, College of Education-Ibn Rushd, University of Baghdad, 2016.

5- Ayat Sa'eed Hussein Al-Ameri, Ground Water and the Possibility of Investing It at Abu Ghreib District, Unpublished Master Thesis, College of Arts, University of Baghdad, 2015.

6- Ebtisam Adnan Rahman Al-Hmedawi, The Natural Properties in Al-Qadisiya governorate and Their Spatial Relationship in Making Use of the Available Water Resources, Unpublished Master Thesis, College of Education for Women, Al-Kufa University, 2009.

7- Fu'ad Manhar Algam and Ra'id Kadhem Abed, The Study of Alga Content of Al-Shamiya Drain Water East of Al-Diwaniya Governorate, Orouk Scientific Journal, Issue (2), Year 2008.

8- Ministry of Water Resources, Office of Planning and Follow-Up, Projects of Irrigation and Drainage in Iraq, 2018.

9- Saad Ibrahim Jassim, Environmental Indications of filtrated water in Al-Dora Area-Baghdad, Unpublished Master Thesis, College of Science, University of Baghdad, 2003.

10- Ministry of Water Resources, Office of Planning and Follow-Up, Projects of Irrigation and Drainage in Iraq, 2018

11-Su'ad Abed Bawi, Mohammed Sulaiman Hasan, The Practical Engineering of Environment- Water Examinations, Dar Al-Hikma, Mosul, 1990. 